\title{
PENETAPAN STANDAR WAKTU PROSES DALAM MENINGKATKAN EFEKTIFITAS DAN EFISIENSI PADA PERUSAHAAN BATIK TULIS RUSDI DESA SUMURGUNG KECAMATAN TUBAN - TUBAN
}

\author{
Martha Laila Arisandra \\ Fakultas Ekonomi, Universitas Islam Darul 'Ulum \\ Lamongan unisda.martha@gmail.com
}

\begin{abstract}
Abstrak
Tujuan dari perusahaan melakukan produksi salah satunya adalah dapat menyelesaikan produksinya tepat waktu, oleh sebab itu diperlukan standar waktu produksi yang efektif dan efisien agar supaya meningkatkan daya saing produk yang dihasilkan, dalam penelitian ini waktu standar yang ditentukan oleh perusahaan adalah 860 menit sedangakan dari hasil observasi dilapangan terjadi penyimpangan $\pm 8 \%$, apabila perusahaan mengubah waktu standar maka perusahaan tersebut bisa menghemat 66,76 menit, dengan hasil temuan yang ada, maka peneliti memberikan saran supaya mengganti standar waktu proses produksi, memberi pengarahan terhadap pekerja supaya tidak terjadi pemborosan waktu, menganalisa penyebab pemborosan waktu serta menerapkan quality control.
\end{abstract}

Kata Kunci : standar waktu proses produksi, quality control

\section{PENDAHULUAN}

Sejalan berkembangannya jaman, dunia perdagangan juga berkembang. Era globalisasi tidak membatasi orang untuk berdagang demikian juga konsumen, mereka berhak dan bebas memilih produsen.Dalam menghadapi era globalisasi setiap produsen dituntut untuk bersaing dari segi kualitas barang, oleh sebab itu dalam proses produksinya setiap perusahaan dituntut untuk efisien dan efektif dalam sistem operasioanl karena akan sangat mempengaruhi harga jual suatu barang.

Waktu yang diperlukan untuk pelaksanaan proses produksi dalam perusahaan merupakan hal yang penting pula bagi terlaksananya proses produksi yang baik. Untuk menjaga agar waktu yang diperlukan untuk melaksanakan proses produksi dalam perusahaan ini dapat dipergunakan dengan sebaik-baiknya, maka diperlukan adanya standar waktu proses. Apabila yang bersangkutan mempunyai standar waktu proses untuk pelaksanaan proses produksinya, maka manajemen perusahaan tersebut akan mempunyai kemudahan 
dalam menyusun perencanaan, pengalokasian dan pengendalian tenaga kerja yang ada di dalam perusahaan yang bersangkutan tersebut.

Apabila manajemen perusahaan yang bersangkutan tersebut mengadakan pengamatan dengan teliti, maka sebenarnya akan banyak terdapat manfaat penggunaan standar waktu proses produksi di dalam pabrik. Dengan adanya standar waktu proses, pelaksanaan proses produksi diselesaikan di dalam perusahaan ini akan dapat menjadi teratur, sehingga dapat direncanakan dan dilaksanakan dengan baik.

Perusahaan "Batik Tulis Rusdi" adalah perusahaan kecil menengah yang memproduksi batik dalam berbagai jenis dan ukuran. Agar dalam pelaksanaan proses produksinya tidak ditemukan adanya pemborosan waktu, maka perusahaan harus mempunyai standar waktu proses, dalam menjalankan aktifitasnya selama ini, perusahaan memakai standar waktu yang telah ditentukan sebelumnya. Tapi dalam realisasinya masih ada penyimpangan terhadap waktu proses produksi sehingga segi efektifitas dan efisiensi belum tercapai.

Dari uraian diatas maka peneliti mengambil judul "Penetapan Standar Waktu Proses Dalam Meningkatkan Efektifitas Dan Efisiensi Pada Perusahaan Batik Tulis Rusdi Desa Sumurgung Kecamatan Tuban - Tuban",

\section{TINJAUAN PUSTAKA}

(Purnaningsih, 2004) Hasil perhitungan waktu normal yang dibutuhkan perusahaan meubel YeniFurniture dalam menjalankan proses produksi sebesar 43.65 jam. Sedang rencana waktu perusahaan sebesar 47.45 jam. Perhitungan waktu dari jalur kritis sebesar 44.97 jam, sehingga diperoleh penyimpaangan sebesar 2.49 jam, berarti terdapatkemungkinan $98.17 \%$ untuk memenuhi waktu penyekesaian proyek yang dijadwalkan.

\section{Hubungan standar waktu dengan produktivitas kerja.}

Pengertian standar waktu seperti yang telah dikemukakan di muka yaitu: Waktu yang diperlukan oleh seorang pekerja terlatih untuk menyelesaikan suatu tugas tertentu, bekerja pada tingkat kecakapan yang berlanjut (sustainable rate), serta menggunakan metode mesin, dan peralatan, material dan pengaturan tempat kerja yang tertentu. Produktivitas adalah hubungan antara masukan-masukan dan keluaran-keluaran suatu sistem produktif. (Handoko, 2009:241)

Produktivitas adalah keseluruhan keluaran barang/jasa yang dihasilkan, dibagi dengan masukan-masukan yang dibutuhkan untuk menghasilkan keluaran tadi. (Robbins and Coulter, 1999:99)

Produktivitas akan bertambah bila ada penambahan secara proporsional dari nilai keluaran dan masukan, bilamana masukan dalam keadaan konstan, sedang keluaran yang dihasilkan terus bertambah maka hal ini menunjukkan bahwa sumbersumber produksi (masukan) telah berhasil dilaksanakan, dioperasikan, dimanfaatkan dan dikelola secara efektif dan efesien. Selanjutnya dinyatakan bahwa, seorang telah bekerja dengan produktif jikalau ia telah menunjukkan out put kerja yang setidaknya telah mencapai suatu ketentuan minimal. Ketentuan yang didasarkan atas besarnya keluaran yang dihasilkan secara normal dan diselesaikan dalam jangka waktu yang layak pula. 
Uraian di atas dapat disimpulkan bahwa ada dua unsur yang bisa dimasukkan sebagai kriteria produktivitas yaitu:

a. Besar atau kecilnya yang dihasilkan

b. Waktu kerja yang dibutuhkan untuk menyelesaikan kerja itu

Hubungan waktu kerja dengan produktivitas kerja menurut . (Handoko, 1999:58), bahwa hasil kerja akan sangat dipengaruhi oleh lamanya waktu bekerja, lamanya istirahat dan frekwensi istirahat yang diberikan.

Dengan bekerja sekeras-kerasnya seorang pekerja memang akan menghasilkan out put yang besar, tetapi hal ini akan melelahkan dan tak akan bertahan lama. Sebaliknya jika bekerja dengan sedikit energi yang dikeluarkan akan dapat bertahan lama, tetapi hasil kerja yang akan dicapai akan sedikit sekali. Dengan demikian perlu dicari cara pengeluaran tenaga yang mampu menghasilkan prestasi yang optimal, untuk itu diperlukan standar waktu jam yang tepat, termasuk di dalamnya adanya kelonggaran waktu untuk keperluan pribadi pekerja atau kepentingan yang tidak terduga.

\section{Hubungan standar waktu dengan production planning and control}

Untuk mengetahui hubungan standar waktu dengan production planning and control, maka terlebih dahulu akan ditinjau pengertian production planning and control.

Planning (perencanaan) merupakan salah satu fungsi manajemen. Dalam perencanaan ditentukan usaha-usaha atau tindakan-tindakan yang perlu diambil oleh pimpinan perusahaan untuk mencapai tujuan perusahaan tersebut di masa mendatang.

Menurut Wirasasmita, (1999:396), bahwa :

Production planning (perencanaan produksi) adalah proses mengenai perencanaan, pemilihan dan cara menghasilkan produk-produk yang layak dipasarkan. Dalam perencanaan ini juga ditentukan jumlah jenis, ukuran, corak atau kualitas produk yang akan dihasilkan : kadang-kadang penetapan harga termasuk dalam perencanaan produk.

Perencanaan produksi yang telah dibuat harus diikuti dengan tindakan pengawasan produksi (production control). Perencanaan tanpa adanya pengawasan, hasilnya tidak akan seperti yang dihasilkan/diharapkan, jadi pengawasan produksi dijalankan dengan maksud agar produksi dapat dilaksanakan sesuai dengan rencana yang telah ditetapkan.

Perencanaan pengawasan produksi mengenai tugasnya Reksohadi Pradjo, (1998:232), dapat diperinci:

a. Mengadakan perencanaan produksi (planning)

b. Menentukan jalannya proses produksi untuk barang-barang tertentu (roating).

c. Menentukan bilamana barang tertentu mulai diproduksi dan selesainya sekaligus (scheduling).

d. Menentukan bahwa suatu barang boleh mulai diproduksikan, pemberian perintah mulai mengerjakan barang (dispatching).

e. Melaksanakan follow-up tugasnya itu, termasuk disini mengumpulkan laporankemajuan pekerjaan barang dan menganalisanya. 
Perencanaan dan pengawasan produksi adalah proses rencana yang telah ditentukan dan penetapan sekumpulan kegiatan produksi dan pengawasan kegiatan pelaksanaan dari proses dan hasil produksi, agar tujuan yang diharapkan dapat dicapai. (Handoko, 1999:78).

Jadi perencanaan dan pengawasan produksi merupakan kegiatan pengkoordinasian dari bagian-bagian yang ada dalam melakukan proses produksi. Dalam kaitannya dengan production control dan fungsi pengawasan, Reksohadi Prodjo, (1998:10) :

a. Supervisi yang menjamin agar kegiatan-kegiatan dilaksanakan dengan baik.

b. Pembandingan berusaha mengecek apakah hasil kerja sesuai dengan yang dikehendaki.

c. Koreksi berusaha untuk menghilangkan kesulitan - kesulitan / penyimpangan - penyimpangan baik pekerjaan maupun mengubah rencana yang dipandang terlalu muluk.

Dari penjelasan yang dikemukakan di atas, maka dapat dilihat betapa pentingnya standar waktu dalam production planningand control. Perencanaan yang baik tentunya harus didasarkan pada standar waktu yang tepat pula.

\section{Hubungan standar waktu dengan scheduling}

Hubungan ini perlu diketahui lebih dahulu dua unsur di dalamnya, yaitu unsur standar waktu dan scheduling uraian terdahulu, maka selanjutnya akan dibahas pengertian scheduling. Scheduling adalah alat dimana segala fasilitas perusahaan diintegrasikan ke dalam unit waktu sebagai ukuran dengan kata lain penentuan kapan produk diproduksi. (Reksohadiprodjo, 1997:179).Scheduling adalah pengaturan waktu dari suatu kegiatan operasi. Penjadualan mencakup kegiatan mengalokasikan fasilitas, peralatan dan tenaga kerja bagi suatu kegiatan operasi serta menentukan urutan pelaksanaan kegiatan operasi.(Harjanto, 1997:219).

Teknik penjadualan Harjanto, (1997:220) biasanya dapat digolongkan dalam dua kategori, yaitu:

a. Penjadwalan maju

Dalam penjadualan maju (Forward Scheduling) pekerjaan dimulai seawal mungkin sehingga pekerjaan biasanya selesai sebelum batas waktu yang dijanjikan (due date) namun konsekwensi dari penjadualan maju ini adalah terjadinya akumulasi penyediaan sempat pekerjaan tersebut diperlukan pada pusat kerja berikutnya.Teknik ini mengasumsikan pengadaan material dan operasi di mulai segera setelah pesanan diterima, penjadualan dilakukan atas setiap kegiatan operasi secara berurutan dari awal hingga seluruh kegiatan operasi selesai.

Penjadualan maju banyak dipakai/digunakan dalam perusahaan dimana operasi dibuat berdasarkan pesanan dan pengiriman biasanya dilakukan segera setelah pekerjaan selesai.

b. Penjadualan mundur

Berlawanan dengan penjadualan maju, dalam penjadualan mundur (backward scheduling) kegiatan operasi yang terakhir dijadwalkan lebih dahulu yang secara berturutturut ditentukan jadualnya untuk kegiatan sebelumnya satu-persatu secara mundur. Akhirnya dalam mengetahui waktu tenggang dalam penggudangan barang maka dapat ditentukan kapan saatnya dimulainya operasi. 
Teknik yang digunakan tersebut tergantung dari jumlah pesanan, keadaan operasi dan kompleksitar dari pekerjaannya sendiri. Pemilihan teknik juga tergantung dari pengendalian terhadap waktu kosong dari mesin yang biaya operasinya lebih tinggi dan pengendalian terhadap persediaan dalam proses.

\section{METODE PENELITIAN}

\section{A. Jenis Penelitian}

1. Field Research

Yaitu penelitian secara langsung dilakukan pada perusahaan guna mendapatkan data yang asli yang dipakai sebagai obyek penelitian.

\section{Library Research}

Yaitu pengambilan data yang dilakukan dengan cara mempelajari literatur dan referensi yang berhubungan dengan permasalahan yang dianalisa.

Dalam Library Research ini dilakukan dengan cara :

a. Study penelitian terdahulu.

b. Simulasi dari berbagai teori pendukung.

\section{B. Sumber Data}

Data primer yaitu data yang diperoleh dari semua informasi, keterangan serta datadata lain yang secara langsung diperoleh dari obyek penelitian. Data primer ini meliputi gambaran umum perusahaan, struktur organisasi, data produksi, data pemasaran, data personalia dan lain-lain.

Data sekunder yaitu data yang diperoleh tidak dari sumbernya langsung melainkan sudah dikumpulkan dan sudah diolah oleh pihak lain. Data sekunder ini meliputi data tentang jumlah tenaga kerja, jam kerja tiap hari, data penjualan dan lain-lain.

\section{Metode Pengumpulan Data}

Untuk mendapatkan data-data yang diperlukan sesuai dengan permasalahan, terlebih dahulu data-data dikumpulkan agar dapat menganalisanya dengan cermat dan tepat sehingga dapat diambil suatu keputusan, untuk itu digunakan metode pengumpulan data sebagai berikut :

1. Observasi

Yaitu teknik pengumpulan data dengan menggunakan pengamatan secara langsung ke obyek penelitian. Observasi digunakan untuk memberikan gambaran yang nyata tentang perusahaan yang sebenarnya.

2. Wawancara

Yaitu dengan cara menggali keterangan lisan dari pegawai atau petugas perusahaan yang berkompeten, alasan menggunakan teknik ini adalah untuk mendapatkan informasi yang tidak dapat diperoleh dari observasi. Adapun komunikasi tersebut dilakukan terhadap: 
a. Pimpinan Perusahaan

Yang diperoleh adalah data mengenai keadaan umum produksi, job description dari masing-masing bagian sesuai dengan struktur organisasi yang ada, tujuan dari perusahaan baik tujuan jangka pendek maupun tujuan jangka panjang.

b. Bagian Produksi dan Penjualan

Dari kedua kepala bagian ini nantinya diharapkan akan diperoleh informasi data tentang jumlah produksi, proses produksi, jumlah penjualan dan hasil penjualan serta daerah pemasarannya. Selain itu juga diharapkan memperoleh data tentang beberapa mesin atau alat yang ada dalam proses produksi, dan bagaimana cara pemeliharaan yang dilakukan.

3. Dokumentasi

Yaitu dilakukan dengan mengambil data dari catatan dan dokumen perusahaan yang ada relevansinya dengan obyek penelitian.

\section{Metode Analisis Data}

1. Metode Kualitatif

Analisa yang menyajikan suatu data dalam uraian kata-kata atau uraian.

2. Metode Kuantitatif

Analisa yang menyajikan suatu data yang berbentuk angka-angka dan melakukan perhitungan-perhitungan dengan menggunakan berbagai rumus yang berhubungan dengan masalah yang diteliti untuk mendapatkan kesimpulan dari penelitian, sedangkan alat analisa yang digunakan dalam penelitian ini adalah Time Study (Studi Waktu). Menurut Barry Reander, (2001:245 ). Dengan rumus sebagai berikut :

$\sum$ Waktu tercatat yang diperlukan untuk

melaksanakan elemen dasar tugas waktu

Siklus Rata-rata :

$\sum$ Siklus yang diamati

Waktu Normal :

\{ Waktu Siklus Aktual Rata-rata \} X \{ Faktor Peringkat \}

Waktu Normal Total

Waktu Standar :

$$
1 \text { - Faktor Kelonggaran }
$$

Waktu Standar dapat dikatakan aktif dan efesien jika telah sama atau mendekati pada waktu standar yang telah ditetapkan, tapi jika dalam pelaksanaan proses produksinya melebihi waktu standar yang telah ditetapkan, maka waktu standar yang dicapai tersebut dapat dikatakan tidak efektif dan efisien. 


\section{HASIL DAN PEMBAHASAN}

\section{Penetapan Standar Waktu yang Efektif dan Efisien}

Berkaitan dengan masalah yang dihadapi oleh perusahaan, langkah yang diambil untuk menyelesaikannya adalah dengan menentukan standar waktu yang tepat, sedangkan metode yang digunakan dalam menentukan standart waktu ini adalah dengan menggunakan metode analisa studi waktu (Time Study).

Selanjutnya di bawah ini akan dijelaskan mengenai Peta Aliran Proses beserta standar waktu yang digunakan oleh perusahaan selama ini.

\section{Peta Aliran Proses}

Peta ini memberikan ciri-ciri tentang langkah-langkah pemindahan barang dari satu operasi dengan operasi lainnya dan harus dicantumkan dalam peta aliran proses operasi. Fungsi dari Peta Aliran Proses secara umum adalah:

1. Dapat digunakan untuk mengetahui aliran bahan atau aktivitas manusia, mulai awal masuk dalam suatu proses atau prosedur sampai aktivitas akhir.

2. Memberikan informasi mengenai waktu penyelesaian suatu proses produksi.

3. Khusus menggambarkan aliran yang diamati oleh suatu komponen atau orang secara lebih lengkap.

4. Sebagai alat untuk melakukan perbaikan-perbaikan proses atau metode kerja.

Peta alir proses di bawah ini dapat diketahui jumlah waktu yang di perlukan dalam proses produksi adalah sekitar 860 menit. Begitu juga dengan waktu yang diperlukan untuk tiap-tiap elemen pekerjaan yang jumlahnya lebih besar jika dibandingkan dengan perhitungan waktu tiap-tiap elemen pekerjaan pada tabel 4.4 
Gambar 1. Peta Aliran Proses Pembuatan Batik Batik Tulis Rusdi 2015

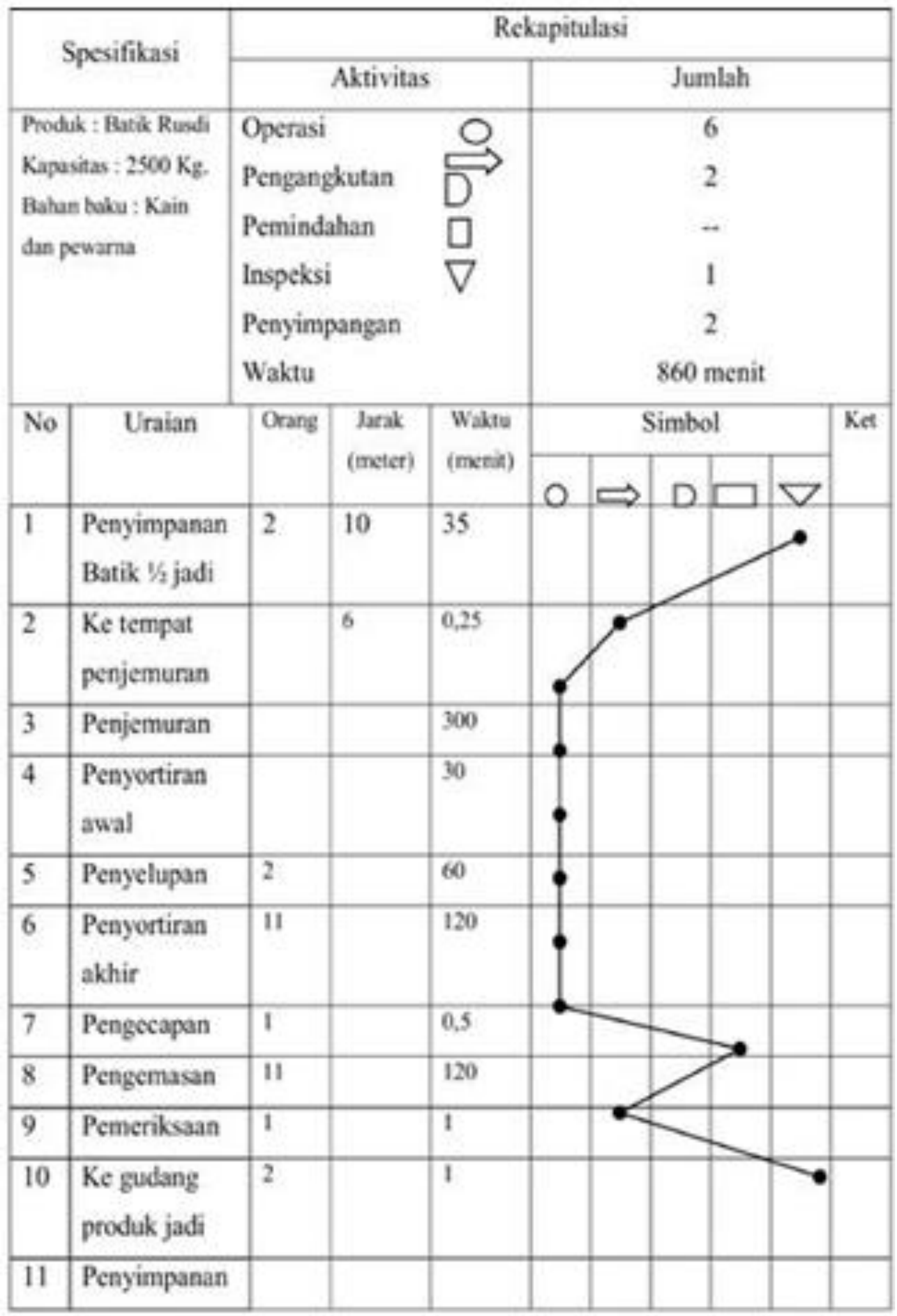

Sumber : data yang telah diolah (2015) 
.Tabel 1. Siklus observasi tiap-tiap elemen pekerjaan

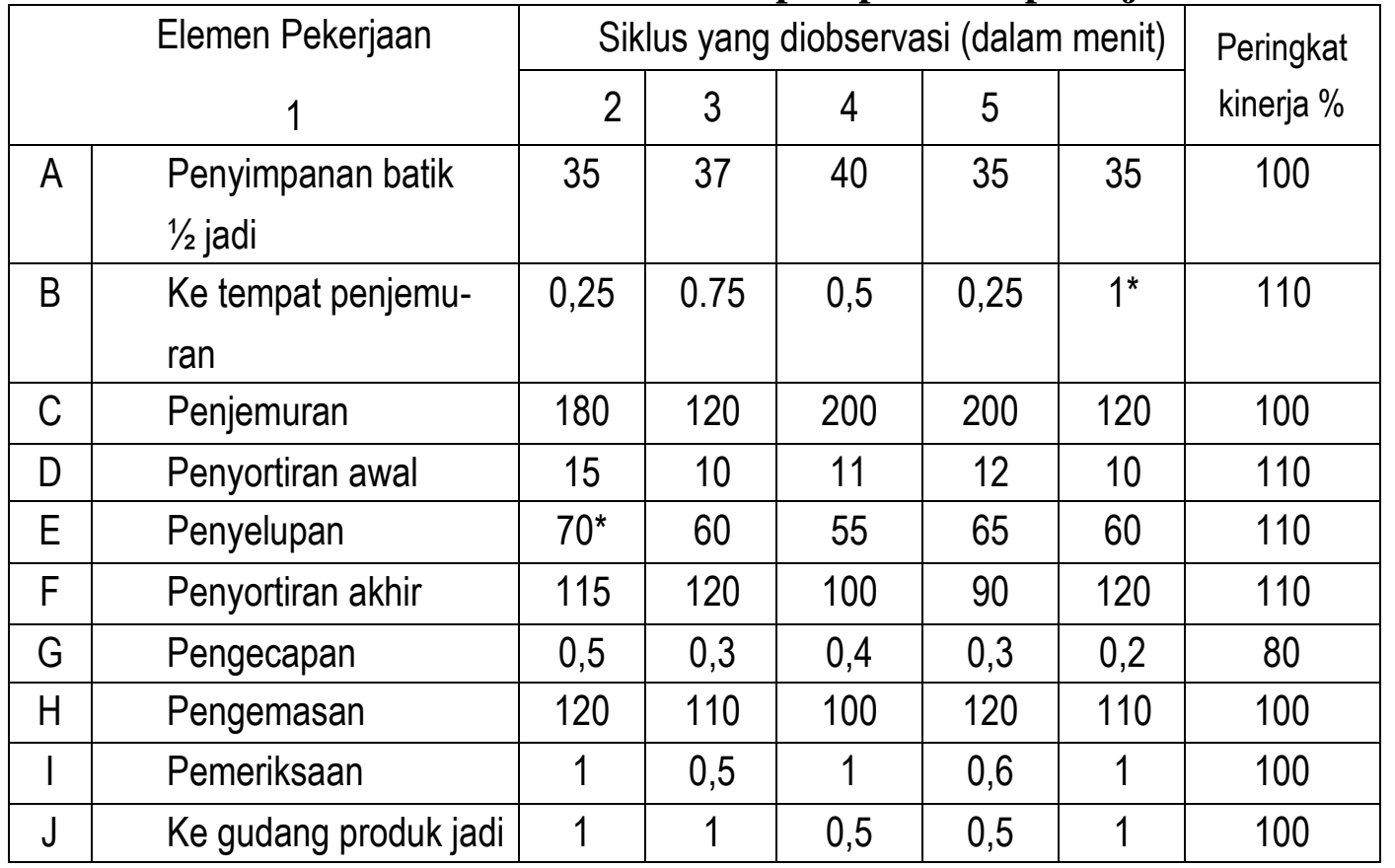

Sumber : Data yang diolah (2015)

Menghapus setiap pengamatan yang tidak biasa dan tidak terjadi berulang kali, misalnya pengamatan yang ditandai dengan * (hasil pengamatan yang seperti ini biasanya oleh kemacetan, Interupsi pekerjaan atau kesalahan yang penyebabnya tidak biasa atau keteledoran, ini bukan merupakan bagian dari pekerjaan).

Bobot faktor prestasi $100 \%$ menggambarkan prestasi kerja normal dimana sebuah faktor yang mempunyai bobot di bawah $100 \%$ menggambarkan prestasi di bawah rata-rata dan bila di atas $100 \%$ mengidentifikasikan prestasi di atas normal, bobot faktor biasanya besarnya antara $80 \%-120 \%$.

1. Menjumlah waktu normal untuk setiap elemen pekerjaan agar dapat diketahui waktu normal total ( Waktu normal untuk keseluruhan pekerjaan ).

Waktu Normal Total $\quad=182+0,47+180,4+11,6+66+119,9+0,27+112+0,82$ $+0,8=674,26$ Menit

2. Menghitung waktu standar untuk pekerjaan-pekerjaan tersebut.

$\begin{aligned} \text { Waktu Standar } & =\frac{674,26}{115 \%} \\ & =793,24 \text { menit. }\end{aligned}$

Standar waktu baru yang di dapat berdasarkan metode studi waktu dengan allowance factor $15 \%$ ini dapat menghemat waktu sebanyak:

- $\quad$ Realisasi pelaksanaan produksi $\quad 860$ menit

- $\quad$ Standar waktu baru $\frac{793,24 \text { menit }}{66,76 \text { menit }}$ 
Atau dengan prosentase : $=\frac{66,76}{793,24} \times 100 \%=8 \%$

Dari hasil perhitungan tersebut ternyata telah memenuhi persyaratan yang diminta perusahaan yaitu penyimpangan atas studi waktu sebesar $+8 \%$. Dengan demikian untuk realisasi pelaksanaan proses produksi selanjutnya, perusahaan dapat menghemat penggunaan waktu proses produksi sebesar 66,76 menit.

Studi waktu merupakan suatu proses pengujian sampel dan masalah pengujian dalam penentuan waktu siklus aktual rata-rata tentu saja muncul kesalahan (Error). Kesalahan tersebut berdasarkan ilmu statistik, berbeda menurut ukuran sampel dengan berbanding terbalik. Untuk menentukan berapa siklus yang hendaknya ditentukan waktunya, perlu dipertimbangkan bahwa setiap elemen pekerjaan memiliki kemungkinan variasi.

Untuk menentukan ukuran sampel yang cukup, ada 3 hal yang harus dipertimbangkan:

1. Seberapa akurat hasil yang diinginkan.

2. Tingkat kemungkinan ( Confident level) yang diinginkan.

3. Seberapa besar variasi yang terjadi di antara elemen-elemen pekerjaan yang ada.

Rumus untuk mencari ukuran sampel yang cukup dengan adanya ketiga hal di atas; Menurut Reder, (2001:249)

$$
\mathrm{n}=\left[\frac{\mathrm{zS}}{\mathrm{hx}}\right]^{\mathrm{z}}
$$

Dimana :

$\mathrm{h}=$ Tingkat keakuratan yang diinginkan

$\mathrm{z}=$ Jumlah standar deviasi yang diperlukan untuk tingkat keyakinan yang disukai.

$\mathrm{S}=$ Standar deviasi dari sampel awal

$\mathrm{x}=$ Mean dari sampel awal

$$
\begin{aligned}
& \mathrm{S}=\sqrt{\frac{\sum\left[\mathrm{x}_{1}-\overline{\mathrm{x}}\right]^{2}}{\mathrm{n}-1}} \\
& \text { Dimana : } \\
& \mathrm{x}_{1}=\text { Nilai setiap pengamatan } \\
& \mathrm{x}=\text { Mean dari pengamatan } \\
& \mathrm{n}=\text { Jumlah pengamatan }
\end{aligned}
$$


Tabel 2. Ukuran Sampel yang Direkomendasikan tiap-tiap Elemen Pekerjaan

\begin{tabular}{|c|c|}
\hline Elemen Pekerjaan & Ukuran Sampel ( Dalam menit ) \\
\hline A & 15 \\
B & 1444 \\
C & 266 \\
D & 136 \\
E & 36 \\
F & 64 \\
G & 369 \\
H & 24 \\
I & 552 \\
J & 486 \\
\hline
\end{tabular}

Sumber : Data yang diolah (2015)

\section{SIMPULAN DAN SARAN}

\section{Simpulan}

Dalam menjalani aktivitas selama ini, perusahaan menggunakan standar waktu sebesar 860 menit yang telah ditetapkan sebelumnya. Akan tetapi dalam realisasinya masih ada penyimpangan terhadap waktu proses produksi.

Untuk menetapkan standar waktu proses produksi yang efektif dan efesien maka perusahaan sebaiknya menerapkan standar waktu yang baru. Hal ini dilakukan karena setelah melakukan analisa terhadap masalah yang timbul dalam perusahaan, maka dapat disimpulkan bahwa selama ini terdapat penyimpangan sebanyak $+8 \%$ dari waktu proses produksi. Hal ini dapat dilihat dari perbandingan antara realisasi pelaksanaan proses produksi dengan standar waktu yang baru.

Jadi dalam penelitian ini peneliti dapat menyimpulkan bahwa studi waktu merupakan suatu proses pengujian sampel dan masalah pengujian dalam penentuan waktu siklus aktual rata-rata tentu saja muncul kesalahan (Error). Kesalahan tersebut berdasarkan ilmu statistik, berbeda menurut ukuran sampel dengan berbanding terbalik. Untuk menentukan berapa siklus yang hendaknya ditentukan waktunya, perlu dipertimbangkan bahwa setiap elemen pekerjaan memiliki kemungkinan variasi.

Saran

Saran yang dapat peneliti kemukakan sebagai solusi pemecahan masalah adalah sebagai berikut : 
1. Perusahaan hendaknya perlu merubah standar waktu lama dengan standar waktu baru sehingga tercapai efektifitas dan efisiensi telah sesuai dengan yang diharapkan perusahaan.

2. Perusahaan hendaknya memberikan petunjuk dan pengarahan pada para karyawan mulai cara pengerjaan yang tepat sehingga dapat menghindarkan terjadinya pemborosan waktu.

3. Perusahaan perlu mengadakan penganalisaan terhadap adanya penyimpangan waktu proses yang terjadi, berikut tindakan-tindakan yang harus dilakukan dan usulan tindakan yang harus diambil.

4. Perusahaan hendaknya menerapkan quality control dengan harapan agar dalam pelaksanaan proses produksi dapat dengan mudah diawasi sehingga segi efektifitas dan efisiensi dapat tercapai.

Demikian simpulan dan saran yang dikemukakan untuk menunjang pemecahan masalah pada perusahaan.

\section{DAFTAR PUSTAKA}

Handoko, T.H. 2009. Dasar-dasar Manajemen Produksi dan Operasi. Edisi Pertama. Yogyakarta: BPFE.

Harjanto, Eddy. 1997. Manajemen Produksi dan Operasi. Jakarta: PERUSAHAAN Grasindo

Purnaningsih. 2004. Analisa penentuan waktu standar produksidalam kaitannya dengan perencanaan danpengawasan produksi pada perusahaan meubel yeni furniture di SerenanJuwiring klaten Fakultas Ekonomi Universitas Muhammadiyah Surakarta.

Reksohadi Pradjo, Sukanto. 1998. Manajemen Produksi dan Operasi. Edisi Ketiga. Yogyakarta: BPFE.

Render, Barry. 2001. Prinsip-prinsip Manajemen Operasional. Edisi Pertama. Jakarta: Salemba Empat.

Robbins, Stephen P and Mary. 1999. Manajemen. Terjemah T. Hermaya. Edisi Keenam Jilid Kedua. Jakarta: Perusahaan Prenhallindo.

Wirasasmito, Rivai. 1999. Kamus Ekonomi. Bandung: CV. Pionir Jaya. 